All Papers

Osgoode Hall Law School of York University Osgoode Digital Commons

Research Papers, Working Papers, Conference

2011

\title{
Challenges to the Patent System
}

Giuseppina D'Agostino

Osgoode Hall Law School of York University, gdagostino@osgoode.yorku.ca

Follow this and additional works at: http://digitalcommons.osgoode.yorku.ca/all_papers

\section{Repository Citation}

D'Agostino, Giuseppina, "Challenges to the Patent System" (2011). All Papers. Paper 14.

http://digitalcommons.osgoode.yorku.ca/all_papers/14

This Working Paper is brought to you for free and open access by the Research Papers, Working Papers, Conference Papers at Osgoode Digital

Commons. It has been accepted for inclusion in All Papers by an authorized administrator of Osgoode Digital Commons. 


\section{Challenges to the Patent System \\ By Giuseppina D’Agostino*}

\section{A Introduction}

One of the underlying justifications of the patent system is to encourage dissemination of scientific knowledge and promote innovation. ${ }^{1}$ Yet, the patent system is not a green card to innovation. Indeed, given our progress in science and the increasing rate of technological developments it is ironic that there is arguably a declining rate of innovation. ${ }^{2}$ From this perspective, it might be contended that the patent system is not meeting its said objectives. But the patent system should be seen in a wider context. While well-intended, it is far too simplistic to argue that patents are good or bad for innovation, or that they 'freeze or spur' innovation. ${ }^{3}$ The challenges to the patent system are complex and

\footnotetext{
*DPhil (Oxford); Member of the Bar of Ontario; Associate Professor of Law, Osgoode Hall Law School, York University, Canada. Thanks to the UK's former Strategic Advisory Board for Intellectual Policy (SABIP) bringing together a top group of experts to review my article and to Hashim Ghazi, Jonathan Giraldi, Nathan Fan, Nirav Bhatt and Essien Udokang for their research assistance.

${ }^{1}$ World Intellectual Property Organization (WIPO), "R\&D, Innovation and Patents", online: WIPO $<$ http://www.wipo.int/patent-law/en/developments/research.html>; Vincent J. Napoleon, "Impact of Global Patent and Regulatory Reform on Patent Strategies for Biotechnology" (2008) $1 \mathrm{~J}$. Tech. L. \& Pol'y 3.

${ }^{2}$ See generally, J. Huebner, "A Possible Declining Trend for Worldwide Innovation" (2005) 72 Technological Forecasting \& Social Change 980 at 980-86; In Canada, see Council of Canadian Academics, Innovation and Business Strategy: Why Canada Falls Short (Ottawa: Council of Canadian Academics, June 2009), online: Council of Canadian Academics <http://www.scienceadvice.ca/documents/(2009-06-11)\%20Innovation\%20Report.pdf>; See also Mario Coccia, "Democratization is the detriment of technological change" (2008) CNR-Ceris Working Paper No. 6, online: Conisglio Nazionale delle Richerche (CNR)-Ceris $<$ http://www.ceris.cnr.it/ceris/workingpaper/2008/WP 608 COCCIA.pdf>; In the pharmaceutical industries drug attrition is a mounting problem: I. Kola \& J. Landis, "Can the pharmaceutical industry reduce attrition rates?" (2004) 3 Nature 711 [Kola \& Landis].

${ }^{3}$ F. Lévêsque \& Y Ménière, "Patents and Innovation: Friends or Foes?" (December 2006) Centre d'économie industrielle Ecole Nationale Superieure des Mines de Paris at 3 [Lévêsque \& Ménière] (the title belies the multi-faceted study on various aspects of the patent system); $R$. Thomas, "Debugging Software Patents: Increasing Innovation and Reducing Uncertainty in the Judicial Design of Optimal Software Patent Law," online: SSRN <http://ssrn.com/abstract=1114065>; S. O'Connor, "IP Transactions as Facilitators of the Globalized Innovation Economy" (Lecture delivered at Entrepreneurship, Innovation and
} 
cannot solely be attributed to its laws. That is, the patent system's constituting laws do not tell the full story. Often more telling are the institutional frameworks and socio-cultural and economic practices at the pre-patent inventive stage and the post-patent commercialization stage and beyond. And so when attempting to predict future developments, and ultimately, craft solutions, understanding and ensuring that the wider context is effective is paramount.

In order to anchor this discussion which explores the challenges in the existing patent system and in the possible solutions, the institutional aspects of the patent system, which play a material role alongside the law, will be examined. For example, while technology has facilitated online filing, patent application costs remain prohibitive. Technology could be used more effectively to minimize these costs and equalize the playing field. At the same time, with the speed of technological developments, patent examiners' knowledge often remains dated. Here the peer-to-patent system being experimented in the UK, Japan, the US and Australia is an attractive mechanism of galvanizing user-generated communities to review patents and infuse fresh and accurate expertise in the examination process. Ultimately, costs might be reduced as well as ensuring that more robust patents are granted. Another opportunity to reshape the patent administration process and to reduce transaction costs especially for poorer applicants, such as independent inventors and universities is to consider a move towards a global patent system, but it too is not without challenges.

Commercializing IP Conference at IP Osgoode and Hennick Centre for Business and Law, York University, Toronto, February 11, 2010), publication pending in R. Dreyfuss et al, Working Within the Boundaries of Intellectual Property (London: Oxford University Press, 2010) (argues that while there are certainly some "bad" patents, IP is generally not a problem, but usefully allows transactions to take place). 


\section{B Challenges in the Patent Context}

\section{IP Discourse: IP is good v IP is bad}

Engaging in absolutist debates that IP is good or IP is bad, and specifically, that patents are good or bad may hinder properly recalibrating the patent system. And so, while not obvious, the dominant discourse surrounding the patent system may present a "challenge" in itself to even beginning a healthy conversation of patent challenges, and eventually, patent reform. Governments may be reluctant to deploy resources to lost cause issues especially where they may lose popularity and votes if they are seen to act in a fashion inconsistent with either mantra. For instance, with the recent prospect of moving towards a globally harmonized patent system, discussed later, the anti-IP camp may challenge governments' willingness to work towards recalibrating the patent system. Such anti-IP/patents-are-bad discourse draws in broad and diverse criticisms, with many that strike at the very merits of patent protection.

Many of the commentators in the anti-IP camp have focused on the negative IP system's effect on global society from ideological, philosophical and sociological perspectives and in varying degrees. ${ }^{4}$ Such perspectives range from gender study criticisms of a "hypermasculinized" IP system, to violations of political and religious ideologies, to human rights concerns over the rights to enjoy the benefits of scientific progress and its application to the right to health,

\footnotetext{
${ }^{4}$ See generally R. Ghafele, "Perceptions of Intellectual Property: A review" online: Intellectual Property Institute (August 2008), online: IP Institute <http://www.ipinstitute.org.uk/pdfs/Perceptions\%20of\%20IP.pdf.> [Ghafele].
} 
food and self-determination. ${ }^{5}$ Many actors have also voiced their criticism of the circumstances surrounding the formation of the TRIPs Agreement, arguing that the forum of negotiation, the WTO, was designed to benefit big business and to encourage a protectionist environment. ${ }^{6}$ Others further argue that because the developing countries were ill-informed and lacked the capacity to represent adequately their position on IP at the WTO, the result was a further entrenchment of the disparity in the North-South divide. ${ }^{7}$

Significant criticism of patent systems has also been seen concerning public health and access to medicines. Strongly driven by NGOs such as Médicins Sans Frontières (MSF) and The Oxford Committee for Famine Relief (OXFAM), the debate largely surrounds the impact of patents on the prices of medicines and the accessibility by those in need, mostly found in developing countries. $^{8}$ Many campaigns have targeted the pharmaceutical industry specifically, often depicting the industry's practice of patenting essential medicines as devoid of morality and corporate social responsibility. ${ }^{9}$ Commentators have similarly explored the ethical dimensions of the

\footnotetext{
${ }^{5}$ Ibid. at 4, 5.

${ }^{6}$ R. Rikowski, “Tripping over TRIPS: An Assessment of the WTO's Agreement on TRIPs, Focusing on Trade, Moral and Information Issues" (2003) 20 Business Information Review; see generally R. Rikowski, "A Marxist Analysis of the World Trade Organisation's Agreement on Trade-Related Aspects of Intellectual Property Rights" (2006) 4(4) Policy Futures in Education 396, online: Policy Futures in Education

<http://www.wwwords.co.uk/pdf/validate.asp?j=pfie\&vol=4\&issue=4\&year=2006\&article=7_Rikow ski_PFIE_4_4_web>.

${ }^{7}$ E. Su, "The Winners and the Losers: the Agreement on Trade-Related Aspects of Intellectual Property Rights and Its Effects on Developing Countries" (2000) 23 Houston Journal of International Law 1.

${ }^{8}$ Ghafele, supra note 4 at 14.

${ }^{9}$ See O. Boateng, "The Profits that Kill", New African (April 2001) 22-27 (summarized Oxfam and The Guardian's "Dying For Drugs" series on the pharmaceutical industry, in which they accused pharmaceutical companies of "systematically using patent rules to squeeze low-cost copies of branded medicines off the market" and for "making too much money for the West" at the expense of the poor in Africa).
} 
pharmaceutical industry's commoditization of patents and have questioned whether it is acceptable to view medicines as a luxury. ${ }^{10}$ Other criticism has centered specifically on the rigidity of the TRIPS Agreement to facilitate access to medicines in developing countries. Critics have argued that many developing countries are still unable to take advantage of such flexibilities due to their lack of technical and administrative capabilities and the "TRIPS-plus" provisions contained in bilateral free trade agreements that have further diminished policy options to protect public health. ${ }^{11}$ It is further argued that the current patent incentive system leads to biomedical products that yield high profits rather than global priority health needs in developing countries. ${ }^{12}$ For example, malaria, pneumonia, diarrhea and TB account for $21 \%$ of the global disease burden, yet only receive $0.31 \%$ of all public and private funds devoted to health research. Further, over 1 billion people, mostly in the developing world, suffer from tropical diseases which are absent or neglected in R\&D.

The debate on IP has also been expanded to include a push for greater access to innovation and scientific progress for the global public good. Critics of the patent system have argued that the propertization and ownership of science and technology inherent to the current system have serious drawbacks on the

\footnotetext{
${ }^{10} \mathrm{M}$. Goozner, "Medicine as a Luxury: the West treats vital pharmaceuticals as just another commodity. If poor countries can't afford filet, why should they get cheap drugs?" (2002) 13 The American Prospect 1.

${ }^{11}$ Report to the Strategic Advisory Board for Intellectual Property Policy (SABIP), Patents in the Global Economy by Duncan N. Matthews, (London: Intellectual Property Office, 2010), online: < http://www.ipo.gov.uk/ipresearch-pglobal-201012.pdf >.

${ }^{12}$ E.R. Gold et al, "Are Patents Impeding Medical Care Innovation?" (2010) 7 PLoS Med 1, at 3 [Gold].
} 
science commons and the general welfare of society. ${ }^{13}$ Such a system also raises ethical issues due to its limitations on access to benefits of research and innovation, resulting in adverse effects on many populations. In what has been described as the anti-commons of biomedical research, critics have argued that the over-allocation of patents to biomedical research has resulted in valuable knowledge remaining underexploited due to limitations of access. ${ }^{14} \mathrm{~A}$ notable example of this effect is found with the human genome, where $20 \%$ of the genes are held under U.S. patents, the majority of which are owned by the private sector. ${ }^{15}$ Critics hold that the anti-commons effect results not only from the grant of patent rights, but also from restrictive downstream licensing practices. However, the debate on whether there exists an anti-commons tragedy of limited access remains unresolved as empirical evidence continues to be ambiguous. ${ }^{16}$

While certainly not all such criticisms are unfounded, less rhetoric and more evidence-based reasoning may be warranted in order to more sensibly address the issues facing the patent system. Doing otherwise, and feeding the IP is good, or as noted here, the IP is bad debate, may remain a roadblock to fruitful changes in the years ahead. As will be explored more fully below, debunking the very idea of patent protection, and in doing so across the board, is unhelpful and unrealistic. A more nuanced, evidence-driven conversation would be salutary in the academic, policy and legislative circles. And so, more time, resources and

\footnotetext{
${ }^{13}$ L. Biron "The Rationale for Patents: A Philosophical Perspective", at 7-10; see also The University of Manchester Institute of Science, Ethics and Innovation, "Who Owns Science? The Manchester Manifesto" online: The University of Manchester Institute for Science Ethics and Innovation <http://www.isei.manchester.ac.uk/TheManchesterManifesto.pdf >.

${ }^{14}$ Gold, supra note 12 at 2, 3; S. Piper, "The Tools and Levers of Access to Patented Health Related Genetic invention in Canada” (2009) 30 Wash. U. J. L. \& Pol'y 43 at 43-77.

${ }^{15}$ Ibid.

${ }^{16}$ Gold, supra note 12.
} 
expertise should be allocated to study the issues from various perspectives. At the same time, a critical lens should be cast when presented with any absolutist, catch-all arguments.

\section{$2 \quad$ Wider Context in a Sector-specific Approach}

In light of the absolutist IP discourse that presents a challenge to fixing the patent system in its own right, and the proposed need for greater evidence-driven conversation, the many more challenges that exist are best understood at a sector specific level. Not only have some commentators argued that some patents merit differential treatment, ${ }^{17}$ other studies have suggested that they merit different licensing solutions depending on the industry. Every industry is unique and implicates a host of parties unique to its patent system. ${ }^{18}$ Indeed, ' $\ldots$ downstream commercialization requires coordination among the many complementary users of the patented invention, including, inter alia, developers, manufacturers, laborers, managers, investors, advertisers, and marketers. ${ }^{19}$ In a survey of 229 US and Canadian firms, only $4 \%$ of licensable technologies were found to end up in a license..$^{20}$ Of the 100 licensable technologies, a potential

\footnotetext{
${ }^{17}$ B. Condon \& T. Sinha, "Global Diseases, Global Patents and Differential Treatment in WTO Law: Criteria for Suspending Patent Obligations in Developing Countries" (2005) 26(1) Nw. J. Int'I L. \& Bus. 1 (discussing several WTO mechanisms for implementing special and differential treatment in TRIPS with respect to pharmaceutical patents); K. Outterson, "Should Access to Medicines and TRIPS flexibilities be limited to specific diseases" (2008) 34 Am. J.L \& Med. 279. ${ }^{18}$ Lévêsque \& Ménière, supra note 3 at 74 ; P. Jenkins, "Intellectual Property Rights: Innovation and Commercialization in Turbulent Times" (Lecture delivered at the Conference Board of Canada, Sheraton Hotel, Toronto, 29 May 2009) [unpublished] (commentary of lecture available online at IP Osgoode <http://www.iposgoode.ca/2009/06/conference-board-of-canada-eventhighlights-importance-of-ip-protections/>).

${ }_{19}$ S.F. Kieff, "IP Transactions: On the Theory \& Practice of Commercializing Innovation" (2005) Stanford Law and Economics Olin Working Paper No. 311, online: SSRN <http://ssrn.com/abstract=821327>.

${ }^{20}$ Lévêsque \& Ménière, supra note 3 at 53.
} 
licensee is found in only 25 cases. ${ }^{21}$ Valuable patented technologies are often unexploited. There are various reasons for this including disagreement of royalties between parties, costs to search for potential partners, internal approvals concerning exclusivity, opportunistic behaviour among firms where partners may appropriate disclosed information without a licence. As a result, firms that have existing relationships might engage more easily in licensing agreements. ${ }^{22}$ Overall, the chances that a patent is successfully commercialized and actually returns a profit are extremely low. But when there is commercial success, the rewards can be high. ${ }^{23}$

\section{$3 \quad$ Pharmaceutical and Biotech Industry}

Take the pharmaceutical industry as a case in point. While pharmaceutical patent right holders might argue that the patent protection term is too short, irrespective of the time of protection allocated, pharmaceutical discoveries should become more efficient. The issue is not purely a legal one. Current drug attrition is quite high and even 100 years of patent protection would not solve pharmaceutical woes. ${ }^{24}$ On the contrary, a prolonged term of protection might disincentivize pharmaceutical industries from discovering new drugs. One vehicle for generating new patentable drugs is for pharmaceuticals to partner with universities conducting multidisciplinary research in diverse areas as

\footnotetext{
${ }^{21}$ Ibid. at 53.

22 lbid. at 54.

${ }^{23}$ Ibid. at 64.

${ }^{24}$ Kola \& Landis, supra note 2; I. Kola, "The State of Innovation in Drug Development" (February 2008) 83 Clinical Pharmacology \& Therapeutics 227.
} 
nanotechnology, drug delivery, monoclonal antibodies and stem cells to name a few.

Here the patent system might be improved in order to further promote innovation in universities conducting drug research. For example, patents are prohibitively expensive and universities do not have the resources for national phase filing expenses, legal costs associated with translation between countries and other costs. For instance, any applications filed pursuant to the European Patent Office (EPO) must be written in one of the three official languages: English, French and German. If accepted, patents must be translated in the other two languages and in any country in which the innovators claim a patent. In the result, a European patent activated in 7 countries costs 7,000 euros in translations. Comparatively, a European patent costs on average 24,100 euros to its holder, whereas a US patent 10,250 euros and a Japanese patent $5,460 .{ }^{25}$ Such fees are especially onerous for university-based applicants. Commentators argue that the costs 'should be incurred only if it is outweighed by a larger social benefit in terms of information diffusion, ${ }^{26}$ alas one of the goals of the patent system. But as Lévêsque and Ménière argue this is not the case for most translations which are often unread and only available several years after the patent issuance. Consequently, '[t]his delay is too long relatively to the path of technological change. ${ }^{27}$

\footnotetext{
${ }^{25}$ Lévêsque \& Ménière, supra note 3 at 44.

${ }^{26}$ Ibid.

${ }^{27}$ Ibid.; In addition, several reform projects are underway, such as the Community Patent and the London Protocol, to reduce the cost of translation of European patents in National languages.
} 
Budgetary restraints are particularly acute for patents associated with pharmaceutical and biotechnology applications. One reason specific to these industries is the need to generate pre-clinical data in order to attract an industrial licensee. However, in vivo pre-clinical studies can take from months to years to be completed, yet universities are often forced to file patent applications well in advance in order to secure a priority date. Some may argue that universities should postpone filing biomedical patent applications until after in vivo data is generated, but academic researchers are faced with the predicament that they must publish their data in order to secure a grant to conduct the required in vivo experiments therefore forcing them to file prior to disclosure. Considering the obstacles faced by university technology transfer, the patent system might be adapted to promote innovation within cash strapped universities.

\section{$4 \quad$ University Technology Transfer}

While there are 'deep pocket' university exceptions, the majority of academic institutions can certainly file, but do not have the budget to maintain patents.

Resources are scarce. Universities support researchers through technology transfer offices and advise on how to best commercialize valuable IP. Although these tech transfer offices are a critical resource, all too often individuals with limited industrial experience are recruited. Of course there are the exceptions, MaRS in Toronto is but one example, and in Canada the "Waterloo miracle" is a success story which features a model "innovation 
ecosystem". ${ }^{28}$ Launch Lab for the World is a new Canada-based industry-driven initiative which will draw from various public-private fora, including university know-how to launch the world's innovative technologies. ${ }^{29}$

Due to the limited financial resources, the current innovation model developed in academic commercialization or knowledge-transfer centres is for applicants to secure a licence within a year of filing. Often universities employ a policy to file for a provisional but do not convert the application to the Patent Cooperation Treaty (PCT) phase at one-year, unless a licensing deal is in place. Such a policy results in numerous missed opportunities, especially in the biomedical sciences. Inventors lose their inventions as they are not able to commit to enter the national phase due to the inordinate expenses and lack of support. This raises the concern that valuable patent applications are being dropped too early. And here, it is significant to appreciate that there is no onesize fits all policy.

There are various solutions available to enable promising inventions to make it to the national phase. First, university commercialization centres can soften their pre-national phase licensing rules, or at least, allow biotechnological inventions, often saddled with expensive and time-consuming in vivo trials, more time to materialize viable clinical applications. A second solution, which I will address below, might be to reform the patent administration process to reduce

\footnotetext{
${ }^{28}$ S. Maich, "Why Canada Needs RIM to Win" Canadian Business Magazine (February 15, 2010) 4; M. Castel, "IP Transactions as Facilitators of the Globalized Innovation Economy" (Lecture delivered at Entrepreneurship, Innovation and Commercializing IP Conference at IP Osgoode and Hennick Centre for Business and Law, York University, Toronto, February 11, 2010) [unpublished].

${ }_{29}$ See Launch Lab for the World <www.launchlabfortheworld.com> (Launched at Canada 3.0 Conference, Stratford, Ontario by Tony Chapman, Founder \& CEO of Capital C Communications, 10 \& 11 May 1 2010).
} 
transaction costs especially for poorer applicants, such as independent inventors and universities by considering (1) a move towards a global patent system; (2) relying on peer-to-patent initiatives; and, (3) implementing student-ran commercialization clinics.

\section{Challenges in the Solutions}

\section{A Move Towards a Global Patent System?}

Commentators are divided on whether a global patent system is desirable. Desirability is contingent on one's objectives for the patent system, and typically on a global scale, differs depending on whether the perspective is from a developed or developing nation. ${ }^{30}$

\section{(a) Benefits}

A global patent system is generally believed to reduce transaction costs (namely, filing fees and potential litigation). In the pharmaceutical and biotech context, a global patent system could cut down on expenses to assist parties in filing after pre-clinical studies. Commentators justify the need for a harmonized patent system to aid the globalization of commerce, reduce trade barriers and bolster stability and predictability in international patent protection. ${ }^{31}$ More

\footnotetext{
${ }^{30}$ Though there are certainly exceptions, see E. Alsegård, "Global Pharmaceutical Patents after the Doha Declaration: What Lies in the Future" (2004) 1(1) SCRIPTed 12, online: University of Edinburgh, SCRIPTed <http: www.law.ed.ac.uk/ahrc/script-ed/docs/doha.asp> (argues for the global protection of intellectual property rights for developing countries).

${ }^{31}$ See e.g. R.R. Willis, "International Patent Law: Should United States and Foreign Patent Laws Be Uniform? An Analysis of the Benefits, Problems, and Barriers" (2009) 10 N.C. J.L. \& Tech. 283 at 300 .
} 
specifically, the five most common arguments for patent harmonization include: (1) reduction of patent costs by exchange of results between examining patent offices; (2) reduction of problems and errors during the prosecution of patent applications in foreign countries; (3) worldwide patent protection becomes effective; (4) each step of harmonization leads to further harmonization; and (5) further step-by-step harmonization may finally motivate the United States to give up the principle of first to invent. ${ }^{32}$ Indeed, the United States has been reluctant to change its domestic policies to align more with the international community, notwithstanding its push for a more global system. The Patent Reform Act of $2009^{33}$ represents the third consecutive congressional session to attempt the first overhaul of the U.S. patent system since 1952 and among its various proposals, switch from a first to invent to first to file system and make its domestic policy more congruent with its international counterparts. ${ }^{34}$ From an access to justice perspective, enforcement of patent suits would be more convenient and less expensive. Indeed, a law allowing a patent holder to consolidate multiple infringing acts in a single suit might not only save money but provide the only means for the patent holder to obtain redress. ${ }^{35}$ Of course, here one would have

\footnotetext{
${ }^{32}$ Ibid.

${ }^{33}$ U.S., Patent Reform Act, 111th Cong. (2009) (Mar 3, 2009) at s. 515, online: GovTrack.us <http://www.govtrack.us/congress/bill.xpd?bill=s111-515>.

${ }^{34}$ Most countries operate on a first-to-file system. For commentary, see A. Sabatelli \& J.C. Rasser, "Impediments to Global Patent Law Harmonization" (1995) 22 N. Ky. L. Rev. 579; A.M. Seifert, "Will the United States Take the Plunge into Global Patent Law Harmonization? A Discussion of the United States' Past, Present, and Future Harmonization Efforts" (2002) 6 Marq. Intell. Prop. L. Rev. 173; R.K. Dickey, "The First-to-Invent Patent Priority System: An Embarrassment to the International Community" (2006) 24 B.U. Int'I L.J. 283; H. Waters, "US switch to first-to-file patents could cause minor shake-up" (2011) 17 Nature Medicine 906.

${ }^{35}$ S. Fernandes, "Annual Review: Intellectual Property: Patent: Note: Microsoft Corp. v. AT\&T: A Welcome Return to Patent Law's Tradition of Territoriality" (2008) 23 Berkeley Tech. L.J. 75 at $100-1$.
} 
to be a patent holder to begin with or have a claim to be protected, and be versed with the litigation process in the first place.

\section{(b) Disadvantages}

Typically the two most common sources of resistance are ideological and economic. Ideologically, three reasons typically lead to opposing patent harmonization: (1) reluctance of national governments to refashion their current systems; (2) abdicating on some national sovereignty in favour of a global system; and (3) reconciling various interests between the developing and developed world. ${ }^{36}$ Economically, there is an inordinate cost to implement a global patent system: to align the myriad domestic policies with an international standard, account for the early expense of administration (notwithstanding the future reduction in cost) and to determine a unified court system. As well, there is a strong argument insisting that were there to be a global system, special and distinct treatment would have to be carved out for unique entities, such as developing nations and pharmaceutical/biotech industries. A global patent system might also present potential for abuse by more powerful companies and states, and would have to have a robust review mechanism in place.

\section{(c) Global Patent Points to Ponder}

As nations are transforming from industrial-based to information-based economies, protection of intellectual property will affect trade issues on a global

\footnotetext{
${ }^{36}$ Ibid. at 301.
} 
scale and necessitate a more collaborative approach to patent law. ${ }^{37}$ Whether under the aegis of a global patent system, more coordination at the international level will be important. A number of areas of synchronization have been identified as necessary: a uniform definition of patentable subject matter, uniform filing and application procedures, uniform examination and grant procedures, and uniform interpretation, remedies and enforcement. As noted, the United States is moving towards a first to file system, though far from harmonized. An implementation of a globally harmonized first to file system would allow American inventors to file patent applications in English and supply a translated application at a later time. This would help to eliminate the current race to submit patents in foreign countries and the current dangers associated with translation errors in foreign application and the difficulties of correction after submission. ${ }^{38}$ Similarly, in Europe, continental harmonization faces various obstacles with the cost of translating an application to obtain a patent. Translation costs and various fees, is three to five times more expensive than a United States or Japanese patent. Another major disadvantage in Europe is the lack of a Community Patent Appeal Court, analogous to the federal Court of Appeals in the United States. ${ }^{39}$ A harmonized patent system in Europe would allow the patent to issue in all member states instead of the applicant having to choose the country of choice.

\footnotetext{
${ }^{37}$ R.L. Campbell, "Global Patent Law Harmonization: Benefits and Implementation" (2003) 13 Ind. Int'। \& Comp. L. Rev. 605 at 605 [Campbell]; A.R. Sommer, "Trouble on the Commons: A Lockean Justification on Patent Law Harmonization" (2005) 87 J. Pat. \& Trademark Off. Soc'y 141.

${ }^{38}$ Campbell, ibid. at 623.

39 Ibid. at 625-27.
} 
The patent would be subject to one interpretation throughout the world, a central court and administering body, and considerable reduction in translation costs. ${ }^{40}$

Another misconception when criticizing a global patent system seems to be that technology is only generated in developed nations, rather than in developing nations. Consequently, it is often presumed that 'weak protection for intellectual property will assist in obtaining developed country technology at little or no cost. ${ }^{41}$ Intellectual property protection may help generate the development of more technology in developing countries. Here, Mexico is cited as an example where once its patent laws were reformed in 1991, large numbers of patents were filed and were directly linked to contribute to local activity. ${ }^{42}$ A similar increase in technological development was seen in China in the late 1970s, when the country reformed its legal and economic policies to foster its involvement in the global economy. ${ }^{43}$ Also, consider that venture capital firms will not invest in technology without some certainty that their technologies are protected ${ }^{44}$. And from a university commercialization perspective, '[t]he expected synergy in these research parks has not appeared at the levels observed in countries with highstimulation systems', ${ }^{45}$ which include patent protection. In reconciling the global patent harmonization differences, one relevant policy question might be, to what

\footnotetext{
${ }^{40} \mathrm{Ibid}$. at 627.

${ }^{41}$ Ibid. at 629.

${ }^{42}$ R. Sherwood, "Why a Uniform Intellectual Property System Makes Sense for the World" in M.B. Wallerstein et al., eds., Global Dimensions of Intellectual Property Rights in Science and Technology (Washington: National Academy Press, 1993) 68 at 73

${ }^{43}$ R.M. Gabriel, "The Patent Revolution; Proposed Reforms in Chinese Intellectual Property Law, Policy, and Practice are the Latest Step to Bolster Patent Protection in China" 9(2) Asian-Pacific Law \& Policy Journal 323 at 328-330, online: University of Hawaii $<$ http://www.hawaii.edu/aplpj/articles/APLPJ_09.2_gabriel.pdf>. ${ }_{44} \mathrm{lbid}$. at 329.

45 J.F. Duffy "Patent System Reform: Harmony and Diversity in Global Patent law" (2002) 17 Berkeley Tech. L.J. 685.
} 
extent should interjurisdictional diversity and competition be sacrificed to achieve global uniformity $?^{46}$ John Duffy argues that uniformity makes laws unresponsive to local variations, eliminates interjurisdictional competition and decreases possibilities for legal experimentation. ${ }^{47}$ The speculated dangers here are that with a uniform system the entire world would serve as a "laboratory" as experiments would be spread out temporally and not geographically. This might lead to decreased innovation and data outputs might be harder to interpret with the lack of a good control. ${ }^{48}$ While these claims are at best speculative, local diverse communities should not be completely outlawed for a single monolithic code. Again, it is worth noting that such challenges are not isolated to patent or intellectual property laws more broadly, but span most other legal systems.

At the same time, it is unrealistic to assume that a unitary patent system will optimally encourage innovation in the wide range of diverse industries that it is expected to cover. Indeed, the rules applied to different industries increasingly diverge; some examples are found in biotechnology and computer software cases where courts have diverged in applying common law legal standards of obviousness, enablement and written description. ${ }^{49}$ Rather, as Dan Burk and Mark Lemley argue it might be more opportune to enable courts to tailor patent law to the needs of specific industries. Administrative agencies might also have a role in shaping statutory applications. In Canada, the Canadian Intellectual

\footnotetext{
${ }^{46}$ Ibid.

${ }^{47}$ Ibid. at 685.

${ }^{48}$ Ibid. at 691.

49 D.L. Burk \& M.A. Lemley, "Policy Layers in Patent Law" (2003) 89 Va. L. Rev. 1575 at 1577-78; J.C. Fromer, "Layers of Obviousness in Patent Law" (2008) 22 Harv. J. L. \& Tech. 75, online:

SSRN <http://ssrn.com/abstract=1119723>.
} 
Property Office, in the US, the Patent Trademark Office and, in the UK, the Intellectual Property Office, each plays such a fundamental role.

\section{Patent Administrative Offices - Peer-to-Patent Initiatives}

There are mounting problems in the patent administration process and its recalibration could present the most immediate and effective way to bolster the viability of the patent system. As Peter Drahos argues, '[T]he vast majority of patents begin and end their life in a patent office ... It is the daily patent office routines of a country that determine the build-up of patents in an economy, including pharmaceutical patents. ${ }^{50}$ At the USPTO and the EPO, there is an inordinate backlog of over a million patents to prosecute and patent examiners spend less than 30 hours per application. ${ }^{51}$ Delays in patent examination are problematic since applicants in the US for instance, will often specify other countries in which they want to preserve their US filing date but delay filing in these other jurisdictions until there is an outcome on the likelihood of patentability of the invention. In theory, this would save applicants money so as to avoid incurring needless expenses. But long delays in the examination process mean

\footnotetext{
${ }^{50}$ P. Drahos, "'Trust Me': Patent Offices in Developing Countries" (2008) 34 Am. J. L. and Med. 151 at 152.

${ }^{51}$ Lévêsque \& Ménière, supra note 3 at 3; A.K. Rai, "Growing Pains in the Administrative State: The Patent Office's Troubled Quest for Managerial Control" (2009) 157 U. Pa. L. Rev. PENNumbra 2051 at 2058 [Rai] (“...according to the PTO"s own statistics, the elapsed time before an applicant receives an initial response from the PTO increased from 21.1 months in 2005 to 25.6 months in 2008. At the end of Financial Year 2008, the PTO had not even begun review of over 770,000 applications. A total of 1,276,028 were listed as pending--that is, either awaiting initial review or in the review process").
} 
that "the time window for seeking international protection may close. ${ }^{.52}$ In addition to the substantial delays, patent examiners often lack the wide-ranging technical expertise in reviewing the breadth of submitted applications. These limitations are significant especially given that important decisions are made on whether to grant 20 year monopolies for inventions that will shape the future of an industry and fundamental research. ${ }^{53}$ Studies estimate that the deadweight loss of a "loose" patent system from lost innovation is approximately $\$ 21$ billion each year in private costs alone, or nearly $\$ 200$ per household per year. This sizeable deadweight loss constitutes approximately $7 \%$ of annual $R \& D$ spending in the United States." ${ }^{54}$ And as pronounced in Graham v. John Deere Co. ${ }^{55}$ ". . . the primary responsibility for sifting out unpatentable material lies in the Patent Office. To await litigation is, for all practical purposes, to debilitate the patent system . . ." ${ }^{56}$ Third party submissions of prior art are increasingly rare because there is (1) lack of awareness of published patent applications; (2) lack of awareness of ability to submit prior art; (3) the inability to submit comments with prior art; and (4) the presumption of validity if the patent issues. ${ }^{57}$ There is thus an opportunity presented by the convergence of the publication of patent

\footnotetext{
${ }^{52}$ Rai, supra note 49 at 2058. For a review of the Australian administrative patent process, see C. Dent, "Patents as Administrative Acts: Patent Decisions for Administrative Review?" (2008) 30 Sydney L. Rev. 691.

${ }^{53}$ Center for Patent Innovations - New York Law School, Peer-to-Patent First Anniversary Report (June 2008), online: Peer-to-Patent.org $<$ http://dotank.nyls.edu/communitypatent/P2Panniversaryreport.pdf> [Peer-to-Patent First Anniversary Report].

${ }^{54}$ G.S. Ford, T.L. Koutsky, \& L.J. Spivak, "Quantifying the Costs of Substandard Patents: Some Preliminary Evidence" (September 2007) Phoenix Center Policy Paper No. 30, online: SSRN <http://ssrn.com/abstract=1012933>.

${ }^{55} 383$ U.S. 1 (1966).

${ }^{56}$ Ibid. at 18.

${ }^{57}$ M. Schecter, "Peer to Patent US Pilot Results" (IBM, presentation to the Canadian Intellectual Property Office, Ottawa, January 2009) [unpublished] [Schecter].
} 
applications, internet communications, and the emergence of collaborative communities.

Peer-to-Patent initiatives are a way to connect the scientific and innovative arts communities to the patent examination process. ${ }^{58}$ The initiatives are premised on the idea that a public of expert peers can help the patent examiner find and analyse the "prior art" who ultimately can prosecute the patent more comprehensively and efficiently. A web-based system connects public peers to patent examiners. The US, the UK, Australia and Japan are leading the way on this front. From a patent applicant's perspective the benefits are various, including the fact that it is cost-efficient, should result in stronger patents, and reduces application waiting times.

The Institute for Information Law \& Policy at New York Law School's work is particularly noteworthy. The project which began in June 2007 has been driven by consultative workshops, company and foundation support, professional and student teams, USPTO cooperation and a steering committee and advisory board. Its system is premised on simple communication of published patent applications with the consent by participating (volunteer) patent applicants. The system is based on an open, online review and comment system that takes place over the course of four months. The best prior art references with comments are forwarded to the examiner, who retains ultimate carriage of the file. Importantly, the examination is advanced at the top of the examiner queue. The New York Law School results have been positive as there has been enhanced patent

\footnotetext{
${ }^{58}$ Pilot system site: <http://peertopatent.org>; Project web site: $<$ http://dotank.nyls.edu/communitypatent>; see also Peer-to-Patent First Anniversary Report, supra note 53.
} 
system integrity, fewer unworthy patents, and greater confidence in issued patents. ${ }^{59}$

In the first year of the pilot, ${ }^{60} 71$ applications were submitted by 17 unique applicants with 173 prior art references. ${ }^{61}$ Of the 71 applications, 40 were reviewed by experts, with 365 active reviewers taking part in the reviewing process. ${ }^{62}$ The pilot was seen as a success, and in mid-July 2008, the USPTO announced it would extend the pilot a second year until June 15, 2009. ${ }^{63}$ The second year of the pilot saw the number of applications increase from 71 in Year One to 187 total applications at the end of May 2009. ${ }^{64}$ The number of unique applicants increased from 17 to 73 in Year Two of the pilot, citing increased press coverage and the USPTO expanding the eligible subject matter to include patent applications pending in Class 705: Business Methods and E-Commerce. ${ }^{65}$ Furthermore, the number of active reviewers increased from 365 in Year One to 505 in Year Two, a 38 percent increase. ${ }^{66}$ Overall, the growth of the pilot was very positive, and in October 2010, the USPTO and New York Law School jointly announced a new pilot program commencing October 2010 and continuing

\footnotetext{
${ }^{59}$ Schecter, supra note 55.

${ }^{60}$ From June 2007 - April 2008

${ }_{61}^{61}$ Peer-to-Patent First Anniversary Report, supra note 53.

62 Ibid.

${ }^{63}$ Center for Patent Innovations - New York Law School, Peer-to-Patent Second Anniversary Report (June 2009) at 14, online: Peer-to-Patent.org <http://dotank.nyls.edu/communitypatent/CPI_P2P_YearTwo_lo.pdf> [Peer-to-Patent Second Anniversary Report].

64 Ibid.

65 lbid.

${ }^{66}$ Ibid. at 15.
} 
through 30 September, $2011 .{ }^{67}$ Expectations are that the new pilot will draw more success and a new review is currently underway to assess its results.

The success of the US initiative has led to similar pilots forming in other areas of the world, including Japan, Australia and the United Kingdom. In Japan, the Institute of Intellectual Property and Japan Patent Office began its pilot in the summer of 2008 with help from the New York Law School, and there have been over 40 patent applications submitted from 15 applicants, with 115 prior art references. $^{68}$ The success of the project led to the Institute of Intellectual launching Peer to Patent Japan (P2PJ) in the beginning of $2011 .^{69}$ The Queensland University of Technology launched a six month P2P initiative in December 2009 in conjunction with IP Australia and the New York Law School ${ }^{70}$. As of December 2010, there have been 31 patent applications submitted from 18 applicants, with 106 prior art references. ${ }^{71}$ The UK Patent Office launched its P2P pilot on 1 June, 2011. ${ }^{72}$

In the first review of the peer-to-patent pilot project, USPTO Director David Kappos illuminated some of the progress with the program thus far. ${ }^{73}$ There has been an increased interest in the program from innovators and university tech transfer offices, many which have stated that peer-to-patent can help them to

\footnotetext{
${ }^{67}$ United States Patent and Trademark Office, Press Release, 10-50, "USPTO Launches Second Year Peer to Patent Pilot in Collaboration with New York Law School" (19 October 2010), online: USPTO <http://www.uspto.gov/news/pr/2010/10_50.jsp>.

${ }_{68}^{68}$ For more information, visit the Peer to Patent Japan Website <http://www.iip.or.jp/e/e_p2pj/>.

69 Ibid,

${ }^{70}$ For more information, please visit Peer-to-Patent Australia <http://www.peertopatent.org.au/ >; First Year Anniversary Report available online:

<http://www.peertopatent.org.au/P2PAU_1st_Anniversary_Report.pdf>.

71 lbid.

${ }^{72}$ For more information, please visit Peer to Patent UK <http://peertopatent.org.uk/>.

${ }^{73}$ D. Kappos, "Remarks to the New York Law School" (Speech delivered on behalf of USPTO at the New York Law School, New York, 26 March 2010), online: USPTO

<http://www.uspto.gov/news/speeches/2010/Remarks_to_NYLS_Mar26.jsp>.
} 
make early decisions regarding potentially costly patent prosecution. As university research and development often involves "embryonic" technology, the determination of patentability and market value to such emerging areas of technology can often be quite difficult and expensive. However, peer-to-patent can benefit tech transfer offices and private sector firms dealing with emerging technologies as it allows them to rely on the information collected and reported by peer-to-patent contributors when making investment decisions on the potential market value of their patent applications. Kappos also stated that its review of the pilot project shows that arts and technologies will receive the most benefit from peer-to-patent.

The review also highlighted some early challenges, the most notable of which would be in the scaling-up of the program. Kappos noted that many businesses are reluctant to comment on others' patents for fear of willful infringement claims by patentees. The review also found difficulty in finding volunteers to submit prior art. While there were over 600 submissions of art, 37 applications in the pilot did not receive a single submission. Thus, there is a clear challenge in scaling-up the program that would require on-going encouragement of participation. One solution Kappos noted was drawn from the "open innovation" model commonly used in software innovation. Such a model relies upon a set of volunteer "knowledge possessors" who each contribute a certain part in collaboration to create a complex program. Research has shown that an important incentivizing factor in getting programmers involved is that of prestige, as volunteer programmers are often known to each other. In applying this model 
to $\mathrm{P} 2 \mathrm{P}$, groups of technical professionals may enjoy competitive rounds of submitting the best prior art or in demonstrating why a colleague's innovation is patentable or not. Kappos also believes that by expanding the P2P program dramatically, it would create market incentives for companies to invest in submitting prior art on their competitors applications.

There is not much literature yet reviewing the peer-to-patent process. Absent careful study (and more results, as the projects are still at their infancy), only some speculative challenges can be recorded. Such pilot initiatives often involve resources, and require buy-in from key stakeholders. Sometimes the very issues that saddle the patent application process continue in the peer-to-patent process. In Canada, for instance, while CIPO is interested in spearheading such an initiative the bilingual language issue remains a challenge as all entries should be in both French and English to ensure the integrity and transparency of the process. Other issues involve the fact that the peer-to-patent process does nothing to alter operation of the patent laws, which remain unquestioned (e.g. the various standards of validity that may be seen as too weak to allow any patent through). Also peer submissions may be made only strategically by various parties, and might not be made if there is perceived fear of reproach by competitors. Still, more information and transparency would be a welcome ingredient in the patent examination process, especially given the need to make patents as "valid" and attractive to incentive investment as possible.

Ultimately, something should be done to reform the patent administration process. Whether it is a peer-to-patent model and/or one which shifts the 
examination burdens to the private sector, or increases responsibilities to the heaviest users, various creative solutions remain ripe for exploration and further study and action. ${ }^{74}$ There is no denying that more collaboration, which does not necessarily mean uniformity, is necessary. And in terms of access to justice issues, relying on patent litigation to eradicate invalid patents will not work for weaker parties in either developed or developing countries.

\section{Development of Resource-Friendly Innovation Centres}

With the prohibitive costs surrounding the filing of patents, the need for more resource-friendly alternatives for inventors and small businesses especially, is integral to foster innovation. In North America, the development of student-run commercialization clinics provide a low-cost alternative to these needy innovators to support their patent applications.

In Canada, the Intellectual Property and Technology Law Program of Osgoode Hall Law School (IP Osgoode) has partnered with the Ontario Centres of Excellence Centre for Commercialization of Research (OCE-CCR) to create the country's first student-run commercialization clinic, where Osgoode law students will be matched up with OCE-supported companies to help them secure and protect their intellectual property en route to commercial success. ${ }^{75}$ It is the

\footnotetext{
${ }^{74}$ J.R. Thomas, "Patent System Reform: The Responsibility of the Rulemaker: Comparative Approaches to Patent Administration Reform" (2002) 17 Berkeley Tech. L.J. 727; L. Vertinsky "Comparing Alternative Institutional Paths to Patent Reform" (2010) 61(3) Ala. L. Review 501, online: University of Alabama School of Law <http://www.law.ua.edu/lawreview/articles/Volume\%2061/lssue\%203/vertinsky.pdf>. ${ }^{75}$ York U Media Relations, "IP Osgoode and Ontario Centres of Excellence (OCE) create groundbreaking IP clinical program" (3 June 2011) online: <http://news.yorku.ca/2011/06/03/ip-
} 
first of its kind in Canada as it is built on a unique collaboration between a law school and a proven, publicly-funded, innovation accelerator centre.

Launched in September of 2011, the twelve-month pilot program has recruited six law students, the support of Osgoode IP professors and a wellestablished IP firm to oversee the legal work and assist on a variety of intellectual property matters. The initiative initially focuses on patent law, but will eventually cover all areas of intellectual property. The project serves as beneficial to both the students and the inventors. The students invaluable legal training to foster their development as young legal professionals, while the inventors receive highend intellectual property advice through a pro bono avenue that reduces start-up costs. Although this is the first of its kind in Canada, the United States organized a similar program a few years earlier. The USPTO began a pilot program in the Fall $2008^{76}$ involving six academic institutions in Phase One, and an additional ten schools in phase two ${ }^{77}$. Similar to the IP Osgoode/OCE-CCR program, the objective of the initiative was to provide students with a unique opportunity to counsel innovators, artists, entrepreneurs, non-profit organizations and policy makers on extensive ranges of intellectual property and business law issues. ${ }^{78}$

osgoode-and-ontario-centres-of-excellence-oce-create-groundbreaking-ip-clinical-program/>; for more information, visit the IP Osgoode Website <www.iposgoode.ca $>$.

${ }^{76}$ American University Washington College of Law; University of Connecticut School of Law; University of Maine School of Law; William Mitchell College of Law; The John Marshall Law School; and, Vanderbilt Law School.

${ }^{77}$ West Virginia University School of Law; Rutgers Law School, Newark; Richmond School of Law; University of Maryland School of Law; University of Puerto Rico Law School; George Washington University School of Law; Franklin Pierce Law Centre; Howard University School of Law; University of Akron School of Law; and, North Carolina Central University School of Law.

${ }^{78}$ For more information, refer to the USPTO Law School Clinic Certification Pilot website $<$ http://www.uspto.gov/ip/boards/oed/practitioner/agents/law_school_pilot.jsp> 
Such initiatives can assist inventors and smaller firms to develop their technology at a cost that is more reasonable. The continual growth of such initiatives will foster patentable technologies at all levels, thereby reducing some of the barriers to entry faced by businesses with lower research and development budgets.

\section{Concluding Observations}

So in the result, will, or should, we continue to have a patent system at least in the form as we now know it? The literature seems to accept that maintaining the current system is unavoidable, even if working to implement a more global system. Some argue that the only system that can work is the one that is currently in place. Even if a global system were to take shape, there would have to be a section carved out that somehow keeps the good elements of the system we have; diversity between nation states and industries is so substantial that a unified system devoid of consideration for these differences would fail to meet the inherent objective of serving the world community. There is no reason to assume that a unitary patent system will optimally encourage innovation. Ultimately, we should expect that the patent system meets the same objectives of encouraging dissemination of scientific knowledge that has been its traditional rationale, but much like the challenges, the solutions will be varied from the legal to the more practical. Considerations of resources, administration, cultural and social practices are important from the invention to the commercialization stage. Any discussion of the patent system should have this greater context in mind and 
avoid rhetorical absolutism. In other words, challenges to the patent system should be seen in this wider context and proposals for reform, within this more pragmatic context. 